\title{
Metabolic effects of salbutamol: comparison of aerosol and intravenous administration
}

\author{
A NEVILlE, J B D PALMER, J GADDIE, C S MAY, K N V PALMER, L E MURCHISON
}

British Medical fournal, 1977, 1, 413-414

\section{Summary}

The effects of intravenous salbutamol $(4 \mu \mathrm{g} / \mathrm{kg})$ were compared with those of aerosol salbutamol $(200 \mu \mathrm{g})$ in 10 asthmatic patients in a double-blind placebo-controlled study. Both methods of administration produced equal bronchodilatation. Intravenous salbutamol caused significant increases in plasma insulin and glucose levels and a fall in serum potassium concentration in addition to tachycardia and tremor, whereas aerosol salbutamol produced only a small transient increase in the plasma glucose level. The initially raised non-esterified fatty acid levels decreased significantly after aerosol and placebo but not after intravenous salbutamol.

\section{Introduction}

The beta ${ }_{2}$-adrenoceptor agonist salbutamol is often used to relieve airways obstruction and may be administered orally, by aerosol, or intravenously. In addition to its bronchodilator action salbutamol has been shown to cause increases in plasma glucose, non-esterified fatty acids (NEFA), and insulin levels

Department of Medicine, University of Aberdeen, Aberdeen AB9 2ZD

A NEVILLE, B MED BIOL, medical student

J B D PALMER, medical student

J GADDIE, MD, CHB, medical registrar

C S MAY, MB, FRACP, lecturer

K N V PALMER, MD, FRCP, reader

Department of Therapeutics and Clinical Pharmacology, University of Aberdeen, Aberdeen AB9 2ZD

L E MURCHISON, PHD, MRCP, lecturer (now consultant physician, Aberdeen Teaching Hospitals) when given intravenously ${ }^{1}$ and orally ${ }^{2}$ to normal subjects. We compared these metabolic effects when the drug was given in equivalent bronchodilator doses by aerosol and intravenously to asthmatic subjects in a double-blind randomised study.

\section{Patients and methods}

Ten subjects (eight men and two women aged 18-60 years (mean 38 years)) with mild chronic bronchial asthma volunteered for the study. Each patient attended after a 12-hour fast at 9 am on three separate mornings at least 48 hours apart, and bronchodilators were discontinued during this period. An indwelling intravenous cannula was inserted, and patients rested semirecumbent for 30 minutes before two basal recordings of pulse, blood pressure, forced vital capacity (FVC), and forced expiratory volume in one second $\left(\mathrm{FEV}_{1}\right)$ were made using a dry wedge spirometer and two basal blood samples were obtained at 10-minute intervals. On three separate occasions each patient received either salbutamol intravenously $(4 \mu \mathrm{g} / \mathrm{kg}$ over five minutes) and placebo aerosol; placebo injection and salbutamol aerosol $(200: \mathrm{g})$; or placebo injection and placebo aerosol. The order of treatments was double-blind and randomised. The pulse rate was recorded during the injection. Further blood samples were obtained after $2,4,10,15,30$, and 60 minutes, and pulse, blood pressure, and ventilatory function were recorded 15 minutes after the injection. Heparinised blood samples were separated immediately and analyses carried out on plasma concentrations of insulin (by radioimmunoassay), potassium (flame photometry), free glycerol and triglyceride (enzymatic method), and NEFA (Duncombe colorimetric technique). A glucose oxidase method was used to measure plasma glucose. The results were analysed statistically using Student's paired $t$ test, and the NEFA changes in the three groups were analysed by analysis of variance.

\section{Results}

Changes in ventilatory function are shown in table I. There was an equivalent and significant increase after intravenous and aerosol salbutamol compared with placebo. Intravenous salbutamol produced a significant increase in the mean resting pulse rate from 73 beats $/ \mathrm{min}$ to 104 beats $/ \mathrm{min}$ at the completion of injection $(P<0.001)$, and 15

TABLE I-Ventilatory function tests. Results are means $\pm S E$ of mean

\begin{tabular}{|c|c|c|c|c|c|c|}
\hline & \multirow{2}{*}{\multicolumn{2}{|c|}{ Placebo }} & \multicolumn{4}{|c|}{ Salbutamol } \\
\hline & & & \multicolumn{2}{|c|}{ Aerosol } & \multicolumn{2}{|c|}{ Intravenous } \\
\hline & Basal & 15 Minutes & Basal & 15 Minutes & Basal & 15 Minutes \\
\hline $\begin{array}{l}\text { FEV } \\
\text { FVC }\end{array}$ & $\begin{array}{l}1 \cdot 34 \pm 0.20 \\
2 \cdot 67 \pm 0.31\end{array}$ & $\begin{array}{r}1 \cdot 25 \pm 0 \cdot 20 \\
2 \cdot 50^{*} \pm 0.30\end{array}$ & $\begin{array}{l}1 \cdot 46 \pm 0 \cdot 27 \\
2 \cdot 78 \pm 0 \cdot 34\end{array}$ & $\begin{array}{r}1.93^{* * *}+0.27 \\
3.48^{*} \pm 0.30\end{array}$ & $\begin{array}{l}1.33 \pm 0.28 \\
2.50 \pm 0.33\end{array}$ & $\begin{array}{l}1 \cdot 72 * * \pm 0 \cdot 28 \\
3 \cdot 10^{* *} \pm 0.34\end{array}$ \\
\hline
\end{tabular}

Significant difference from mean basal level: $* \mathrm{P}<0.05,{ }^{* * P}<0.01 ; * * * \mathrm{P}<0.001$.

TABLE II-Effects of intravenous salbutamol. Results are means $\pm S E$ of mean

\begin{tabular}{|c|c|c|c|c|c|c|c|c|c|}
\hline & & & Basal & 2 Minutes & 4 Minutes & 10 Minutes & 15 Minutes & 30 Minutes & 60 Minutes \\
\hline $\begin{array}{l}\text { Insulin }(\mathrm{mU} / \mathrm{l}) \\
\text { Glucose }(\mathrm{mmol} / \mathrm{l}) \\
\text { Potassium }(\mathrm{mmol} / \mathrm{l}) \\
\text { Free glycerol }(\mu \mathrm{mol} / \mathrm{l}) \\
\text { Triglyceride }(\mathrm{mmol} / \mathrm{l}) \\
\text { NEFA }(\mu \mathrm{mol} / \mathrm{l})\end{array}$ & $\begin{array}{l}\cdots \\
\cdots \\
\cdots\end{array}$ & $\begin{array}{l}. \\
\because \\
\because \\
\because\end{array}$ & $\begin{array}{c}17 \pm 3 \\
5 \cdot 1 \pm 0 \cdot 1 \\
3 \cdot 9 \pm 0 \cdot 1 \\
380 \pm 49 \\
0 \cdot 465 \pm 0 \cdot 058 \\
1255 \pm 138\end{array}$ & $\begin{array}{rl}49 * * & \pm 11 \\
5 \cdot 7 * * * & 0 \cdot 1 \\
3 \cdot 7 & 0 \cdot 1 \\
376 & =37 \\
0.521 & \pm 0.080 \\
1351 & \pm 175\end{array}$ & $\begin{array}{c}43^{* * *} \pm 9 \\
5 \cdot 8^{* * *} \pm 9 \cdot 1 \\
3 \cdot 7 * \pm 0 \cdot 1 \\
412 \pm 46 \\
0 \cdot 353 \pm 0 \cdot 053 \\
1379 \pm 167\end{array}$ & $\begin{array}{c}37^{* *} \pm 7 \\
5 \cdot 8^{* * *} \pm 0 \cdot 1 \\
3 \cdot 5^{* * *} \pm 0 \cdot 1 \\
361 \pm 35 \\
0 \cdot 406 \pm 0 \cdot 062 \\
1358 \pm 164\end{array}$ & $\begin{array}{c}33 * \pm 5 \\
5 \cdot 7 * * \pm 0 \cdot 1 \\
3 \cdot 7 \pm 0 \cdot 1 \\
383 \pm 40 \\
0 \cdot 395 \pm 0 \cdot 076\end{array}$ & $\begin{aligned} 27^{*} & \pm 5 \\
5 \cdot 5^{*} & \pm 0 \cdot 1 \\
3 \cdot 6 & \pm 0 \cdot 1 \\
288^{*} & \pm 29 \\
0 \cdot 482 & \pm 0 \cdot 057\end{aligned}$ & $\begin{array}{c}16 \pm 3 \\
5 \cdot 2 \pm 0 \cdot 1 \\
3 \cdot 8 \pm 0 \cdot 2 \\
240 * \pm 30 \\
0 \cdot 422 \pm 0 \cdot 072\end{array}$ \\
\hline
\end{tabular}

Significant difference from mean basal level: ${ }^{*} \mathrm{P}<0.05 ;{ }^{* *} \mathrm{P}<0.01 ; * * * \mathrm{P}<0.001$.

Conversion: SI to traditional units-Glucose: $1 \mathrm{mmol} / 1 \approx 18 \mathrm{mg} / 100 \mathrm{ml}$ Potassium: $1 \mathrm{mmol} / 1=1 \mathrm{mEq} / 1 . \mathrm{Glycerol}: 1 \mu \mathrm{mol} / 1 \approx 0 \cdot 0092 \mathrm{mg} / 100 \mathrm{ml}$. Triglyceride: $1 \mathrm{mmol} / 1 \approx$ Conversion: SI to traditional units-Glucose:
$88.5 \mathrm{mg} / 100 \mathrm{ml}$. NEFA: $1 \mu \mathrm{mol} / \mathrm{l} \approx 0.26 \mathrm{mg} / \mathrm{l}$. 
TABLE III-Effects of aerosol salbutamol. Results are means $\pm S E$ of mean

\begin{tabular}{|c|c|c|c|c|c|c|c|c|c|}
\hline & & & Basal & 2 Minutes & 4 Minutes & 10 Minutes & 15 Minutes & 30 Minutes & 60 Minutes \\
\hline $\begin{array}{ll}\text { Insulin }(\mathrm{mU} / \mathrm{l}) & \ldots \\
\text { Glucose }(\mathrm{mmol} / \mathrm{l}) & \ldots \\
\text { Potassium }(\mathrm{mmol} / \mathrm{l}) \\
\text { Free glycerol }(\mu \mathrm{mol} / 1) \\
\text { Triglyceride }(\mathrm{mmol} / \mathrm{l}) \\
\text { NEFA }(\mu \mathrm{mol} / \mathrm{l}) \quad \cdots\end{array}$ & $\begin{array}{l}. \\
\cdots \\
\cdots \\
\cdots\end{array}$ & $\begin{array}{l}\cdots \\
\because \\
\cdots \\
\cdots\end{array}$ & $\begin{array}{rl}13 & \div 2 \\
5 \cdot 1 & =0 \cdot 01 \\
3 \cdot 8 & \pm 0 \cdot 1 \\
378 & =60 \\
0 \cdot 677 & 0 \cdot 074 \\
1179 & =129\end{array}$ & $\begin{array}{rl}16 & \pm 3 \\
5 \cdot 3^{* *} & \pm 0.01 \\
3 \cdot 9 & 0 \cdot 1 \\
342 & =58 \\
0.515^{* *} & 0 \cdot 097 \\
940^{* *} & \pm 87\end{array}$ & $\begin{array}{c}14 \pm 2 \\
5 \cdot 2+0 \cdot 1 \\
3 \cdot 9 \pm 0 \cdot 1 \\
350 \pm 64 \\
0 \cdot 584 \pm 0 \cdot 109 \\
1039 \pm 105\end{array}$ & $\begin{array}{c}16 \pm 4 \\
5 \cdot 1=0 \cdot 1 \\
3 \cdot 9: 0 \cdot 1 \\
357: 53 \\
0.434^{* * *} \pm 0 \cdot 097 \\
932^{*} \pm 81\end{array}$ & $\begin{array}{rl}18 & =3 \\
5 \cdot 2 & 0 \cdot 1 \\
3 \cdot 9 & 0 \cdot 1 \\
302 * * & =49 \\
0.503^{* *} & =0.083\end{array}$ & $\begin{array}{c:c}14 & 3 \\
5 \cdot 1 & 0 \cdot 1 \\
4 \cdot 0 & 0 \cdot 1 \\
269 * * & : 39 \\
0 \cdot 573 & 0 \cdot 112\end{array}$ & $\begin{array}{c}13: 3 \\
5 \cdot 1 \div 0 \cdot 1 \\
4 \cdot 1: 0 \cdot 1 \\
222^{* *}: 33 \\
0 \cdot 617: 0.077\end{array}$ \\
\hline
\end{tabular}

Significant difference from mean basal level: ${ }^{*} \mathrm{P}<0.05 ;{ }^{* *} \mathrm{P}<0.01 ; * * * \mathrm{P}<0.001$.

TABLE IV-Effects of placebo. Results are means $+S E$ of mean

\begin{tabular}{|c|c|c|c|c|c|c|c|c|c|}
\hline & & & Basal & 2 Minutes & 4 Minutes & 10 Minutes & 15 Minutes & 30 Mirutes & 60 Minutes \\
\hline $\begin{array}{l}\text { Insulin }(\mathrm{mU} / \mathrm{l}) \\
\text { Glucose }(\mathrm{mmol} / \mathrm{l})\end{array}$ & $\begin{array}{l}\ldots \\
\cdots \\
\cdots \\
\cdots\end{array}$ & $\begin{array}{l}\because \\
\because \\
\because \\
\therefore\end{array}$ & $\begin{array}{c}14+3 \\
4 \cdot 9 \pm 0 \cdot 2 \\
3 \cdot 8 \pm 0 \cdot 1 \\
341+57 \\
0 \cdot 626+0 \cdot 107 \\
1548+335\end{array}$ & $\begin{array}{rl}12 & =3 \\
5 \cdot 0 & =0 \cdot 1 \\
3 \cdot 8 & 0 \cdot 1 \\
308 & \pm 54 \\
0 \cdot 495^{* *} & \pm 0 \cdot 079 \\
1269 * & \pm 374\end{array}$ & $\begin{array}{c}12: 3 \\
5 \cdot 0=0 \cdot 1 \\
3 \cdot 9 \pm 0 \cdot 1 \\
316: 66 \\
0.556 \pm 0.097 \\
1349: 356\end{array}$ & $\begin{array}{rl}15 & =3 \\
5 \cdot 0 & 0 \cdot 1 \\
3 \cdot 9 & 0 \cdot 1 \\
287 & 70 \\
0 \cdot 495 & 0 \cdot 084 \\
1260^{* *} & =312\end{array}$ & $\begin{array}{c:c}15: 3 \\
5 \cdot 0: 0 \cdot 1 \\
3 \cdot 8: 0 \cdot 1 \\
285: 47 \\
0.466^{* *}: 0.081\end{array}$ & $\begin{array}{c}14: 3 \\
5 \cdot 0: 0 \cdot 1 \\
4 \cdot 0: 0 \cdot 2 \\
280: 47 \\
0 \cdot 499^{*}: 0 \cdot 077\end{array}$ & $\begin{array}{c:c}15 & 3 \\
5 \cdot 1 & 0 \cdot 1 \\
4 \cdot 2 & 0 \cdot 3 \\
198^{* *} & 29 \\
0.547 & 0.082\end{array}$ \\
\hline
\end{tabular}

Significant difference from mean basal level: ${ }^{*} \mathrm{P}<0.05 ;{ }^{*} \mathrm{P}<0.01$.

minutes after injection it was still raised at 84 beats $/ \mathrm{min}(\mathrm{P}<0.01)$, The pulse rate did not change after aerosol salbutamol or placebo, and the blood pressure was unaltered in all three treatment groups. During and after the intravenous salbutamol seven of the 10 patients had finger tremor, four had transient palpitations associated with sinus tachycardia, and two, one of whom also complained of facial flushing, had headache.

After intravenous salbutamol there were significant increases in plasma glucose and insulin concentrations, with a small but statistically significant decrease in serum potassium levels (table II). The only change after aerosol salbutamol was a transient increase in plasma glucose at 2 minutes (table III). No such changes were seen after placebo. In all three groups pretreatment fasting levels of free glycerol and NEFA were raised, and serum triglyceride levels were low. After aerosol salbutamol and placebo, free glycerol, triglyceride, and NEFA levels fell (tables III and IV), whereas NEFA levels tended to increase, though not significantly, after intravenous salbutamol. The mean change in NEFA concentration after intravenous salbutamol $(+108 \mu \mathrm{mol} / 1(+28 \mathrm{mg} / \mathrm{l})$, however, was significantly different from that after both aerosol salbutamol $(-209 \mu \mathrm{mol} / 1(-54.3 \mathrm{mg} / \mathrm{l}) ; \mathrm{P}<0.01)$ and placebo $(-255 \mu \mathrm{mol} / 1(-66.3 \mathrm{mg} / \mathrm{l}) ; \mathrm{P}<0.01)$.

\section{Discussion}

Theoretically the metabolic changes caused by salbutamol may be harmful to the asthmatic patient. We have shown that a standard dose of aerosol salbutamol produced only a minor transient increase in plasma glucose levels and caused no change in plasma insulin or potassium levels, whereas an equivalent bronchodilator dose of intravenous salbutamol did. When salbutamol is given by aerosol, however, the plasma levels of salbutamol are negligible. ${ }^{3}$ We have previously shown that similar changes in glucose, insulin, and potassium occur after oral salbutamol in normal subjects. We have not yet compared the metabolic responses of normal and asthmatic subjects to sympathomimetic amines, but there is evidence that the changes in glucose ${ }^{4}$ and possibly $\mathrm{NEFA}^{5}$ may be smaller in asthmatics during periods of airways obstruction. ${ }^{6}$

Our patients had only mild to moderate airways obstruction. Intravenous salbutamol is used in patients with severe airways obstruction unresponsive to aerosol treatment. In these patients hypoxia, acidosis, and high catecholamine levels increase the risk of dysrhythmias, ${ }^{7}$ and this may be further aggravated by the metabolic changes after intravenous salbutamol. It has been suggested that after myocardial infarction high levels of NEFA are cardiotoxic, ${ }^{8}$ but the concept that high NEFA levels predispose to cardiac arrhythmias is controversial. ${ }^{9}$
Another factor that may predispose to the development of dysrhythmias in asthmatics treated by salbutamol is hypokalaemia, resulting from a shift of potassium from the extracellular to the intracellular space due to the action of insulin or to a direct effect of salbutamol on potassium transport into muscle. ${ }^{10}$ A significant fall in serum potassium from 3.99 to $3.10 \mathrm{mmol}(\mathrm{mEq}) / 1$ during a one-hour infusion of $600 \mu \mathrm{g}$ of salbutamol has been found, ${ }^{11}$ and we have shown a smaller but statistically significant decrease after a lower intravenous dose of salbutamol, although the clinical significance of this is uncertain. The risk of dysrhythmias in salbutamol-induced hypokalaemia is probably determined mainly by two factors: the rapidity with which the intracellular concentration of potassium rises and the extracellular concentration falls, and by the degree of hypoxia of the myocardium. ${ }^{1: 13}$ An additional possible cause of hypokalaemia in patients with severe airways obstruction is the concomitant administration of parenteral corticosteroids in high doses. Although no one has yet shown that the administration of parenteral salbutamol results in cardiac dysrhythmias, it would be prudent to carry out cardiac monitoring of patients who receive intravenous salbutamol for status asthmaticus until it is established whether or not these theoretical hazards are clinically important.

We thank Douglas Morrison and Mrs Grace Taylor for technical help, Dr G M Lees for his advice on preparing the manuscript, and Professor D F Kerridge and Miss I D Fordyce for statistical advice. Requests for reprints should be addressed to Dr K N V Palmer.

\section{References}

${ }^{1}$ Goldberg, R, et al, Postgraduate Medical fournal, 1975, 51, 53.

2 Taylor, M W, et al, British Medical fournal, 1976, 1, 22.

${ }^{3}$ Paterson, J W, and Shenfield, G M, BTTA Review, 1974, 4, 25.

4 Lockey, S D, jun, et al, fournal of Allergy, 1967, 40, 349.

${ }^{5}$ Middleton, E, jun, and Finke, S R, fournal of Allergy, 1968, 42, 288.

${ }^{6}$ Inoue, S, fournal of Allergy, 1967, 40, 337.

7 Collins, J M, et al, British fournal of Pharmacology, 1969, 36, 35.

${ }^{8}$ Oliver, M F, Circulation, 1972, 45, 491.

${ }^{9}$ Opie, L H, Circulation, 1972, 45, 483.

${ }^{10}$ Wang, P, and Clausen, T, Lancet, 1976, 1, 221.

11 Leitch, A G, et al, British Medical fournal, 1976, 1, 365.

12 Hoffman, B F, and Cranefield, P F, American Fournal of Medicine, 1964, 37, 670 .

13 Gelband, H, et al, Circulation Research, 1972, 30, 293.

(Accepted 29 November 1976) 